\title{
Lateral Mobility of Presynaptic $\alpha 7$-Containing Nicotinic Receptors and Its Relevance for Glutamate Release
}

\author{
David Gomez-Varela ${ }^{1,2}$ and Darwin K. Berg ${ }^{1}$ \\ ${ }^{1}$ Neurobiology Section, Division of Biological Sciences, University of California, San Diego, La Jolla, California 92093-0357, and ${ }^{2}$ Max Planck Institute of \\ Experimental Medicine, D-37075 Goettingen, Germany
}

\begin{abstract}
Surface diffusion of postsynaptic receptors shapes synaptic transmission. Presynaptic receptors also influence transmission, but the relevance of their mobility for synaptic function is unknown. Using single-particle tracking with quantum dots, we show that calciumpermeable $\alpha 7$-containing nicotinic acetylcholine receptors ( $\alpha 7$-nAChRs), capable of promoting transmitter release, are mobile on presynaptic terminals but constrained in synaptic space on rat hippocampal neurons in culture. Additional immobilization of presynaptic $\alpha 7$-nAChRs by antibody crosslinking increases glutamate release capacity as seen in the frequency of spontaneous miniature postsynaptic currents and the size of the readily releasable pool of transmitter. Conversely, blocking glutamate release by targeting tetanus toxin to individual synapses increases $\alpha 7-\mathrm{nAChR}$ dwell time at presynaptic sites. The effects on release require functional $\alpha 7-$ nAChRs and may to depend on CAST/ELKS (calpastatin/glutamine, leucine, lysine, and serine-rich protein), which an unbiased proteomic screen yielded. The results support a new homeostatic regulatory mechanism in which $\alpha 7-\mathrm{nAChR}$ restrain may be adjusted as needed at presynaptic sites via active zone proteins to maintain transmitter release capability.
\end{abstract}

\section{Introduction}

Positioning of ligand-gated ion channels at postsynaptic sites is critical for achieving fast chemical transmission. Perhaps best characterized in this respect are AMPA-type glutamate receptors that are recruited to postsynaptic sites by mechanisms depending on lateral diffusion of surface receptors for both synaptic maintenance and synaptic plasticity (Tardin et al., 2003; Adesnik et al., 2005; Ashby et al., 2006; Heine et al., 2008; Makino and Malinow, 2009; Hoze et al., 2012). Numerous types of ligand-gated ion channels are also located presynaptically in which they can modulate transmitter release (Dudel and Kuffler, 1961; Eccles, 1964; Khakh and Henderson, 2000; Duguid and Smart, 2009; Larsen et al., 2011). Although their precise location is important for synaptic function, little is known about the mobility of presynaptic ligand-gated ion channels or how this may influence synaptic transmission.

Nicotinic acetylcholine receptors containing the $\alpha 7$-gene product ( $\alpha 7-$ nAChRs) are located both presynaptically and postsynaptically at many types of synapses in the CNS (Fabian-Fine et al., 2001; Dajas-Bailador and Wonnacott, 2004; Albuquerque et al., 2009). Because of their high relative permeability to calcium

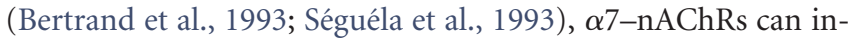

Received April 8, 2013; revised Sept. 18, 2013; accepted Sept. 18, 2013.

Author contributions: D.G.-V. and D.K.B. designed research; D.G.-V. performed research; D.G.-V. analyzed data; D.G.-V. and D.K.B. wrote the paper.

This work was supported by National Institutes of Health Grants NS012601, NS034569, and DA034216 and Tobacco-Related Disease Research Program Grants 17FT-0053 and 19XT-0072. We thank Xiao-Yun Wang and Jeff Schoellerman for expert technical assistance and Massimo Scanziani for comments on this manuscript.

The authors declare no competing financial interests.

Correspondence should be addressed to David Gomez-Varela, Max Planck Institute of Experimental Medicine, D-37075, Goettingen, Germany. E-mail: gomezvarela@em.mpg.de.

DOI:10.1523/JNEUROSCI.1482-13.2013

Copyright $\odot 2013$ the authors $\quad 0270-6474 / 13 / 3317062-10 \$ 15.00 / 0$ fluence a variety of calcium-dependent events, including neuronal development and gene transcription (Jones et al., 1999; Chang and Berg, 2001; Hu et al., 2002; Dajas-Bailador and Wonnacott, 2004; Liu et al., 2006; Albuquerque et al., 2009; Campbell et al., 2010; Miwa et al., 2011; Lozada et al., 2012). A prominent feature of presynaptic $\alpha 7-\mathrm{nAChRs}$ is their ability to enhance transmitter release at both glutamatergic and GABAergic synapses (McGehee et al., 1995; Gray et al., 1996; Alkondon and Albuquerque, 2001; Dickinson et al., 2008; Zhong et al., 2008; Albuquerque et al., 2009; Gu and Yakel, 2011). However, the relationship between the lateral mobility of presynaptic $\alpha 7-$ nAChRs and receptor control of transmitter release is unknown.

A strategy used recently to access the lateral mobility of $\alpha 7-$ nAChRs at postsynaptic sites has been single-particle tracking (SPT) with quantum dots (QDs; Fernandes et al., 2010; GómezVarela et al., 2012). Here we use QDs to show that $\alpha 7-$ nAChRs on presynaptic terminals of hippocampal neurons are mobile but constrained in synaptic space. Immobilizing and clustering presynaptic $\alpha 7-n A C h R s$ by antibody (Ab) crosslinking increases the frequency of spontaneous miniature EPSCs (mEPSCs) and increases the size of the readily releasable pool (RRP) of vesicles. This represents an increase in the capacity for transmitter release. Conversely, silencing transmitter release in a synapse-specific way by using genetically targeted expression of tetanus toxin induces additional constraint of $\alpha 7-n A C h R s$ at presynaptic sites. A proteomics screen suggests that the presynaptic scaffold protein CAST/ELKS (calpastatin/glutamine, leucine, lysine, and serinerich protein) may be associated with $\alpha 7-$ nAChRs and could mediate the $\alpha 7-\mathrm{nAChR}$ effects on transmitter release. The results demonstrate for the first time that the mobility of presynaptic receptors on the cell surface is a critical variable determining transmitter release capability. Control of receptor mobility by the 
nerve terminal may represent both a homeostatic mechanism to sustain release and a novel intrinsic regulatory mechanism to adjust synaptic strength in response to changing demands.

\section{Materials and Methods}

Mass spectrometry of $\alpha 7-n A C h R$ complexes from rat brain. Purification of $\alpha 7$-nAChR complexes, analysis of the samples by mass spectrometry, and database searches were performed as described previously (GómezVarela et al., 2012).

DNA and RNA interference constructs. Synaptophysin-green fluorescent protein (Sph-GFP) and tetanus toxin light chain (TeT) downstream from Sph-GFP (TeT/Sph-GFP) vectors were obtained from Michael Ehlers (Duke University Medical Center, Durham, NC; Ehlers et al., 2007). $\alpha 7-$ HA was obtained from Stephen F. Heinemann (Salk Institute for Biological Studies, La Jolla, CA; Xu et al., 2006). To generate an RNA interference (RNAi) targeting ELKS1, we used the sequence aaggagagcaaattaagttct generated by a Genscript algorithm. The scrambled sequence as control was generated using the Genscript sequence scrambler and was shown not to be homologous to any identified sequence in the rat and mouse genomes. Sequences were inserted into a lentiviral vector (FG12; Addgene plasmid 14884) under an H1 promoter along with GFP under an ubiquitin promoter and were linked to their reverse complement by the loop sequence TCTCTTGAA to form a short-hairpin RNA. Viral particles were obtained by standard techniques. Viral infection was performed by incubating 7-d-old hippocampal cultures with $2 \times 10^{6}$ viral particles for $12 \mathrm{~h}$ at $37^{\circ} \mathrm{C}$. Effectiveness of the knockdown was assessed by ELKS immunostaining in 14-d-old hippocampal cultures.

Hippocampal cultures. Hippocampal cultures were prepared from 18- to 19-d-old Sprague Dawley male and female rat embryos as described previously (Kawai et al., 2002). Briefly, hippocampi were removed rapidly under stereomicroscopic observation, cut into small pieces, and digested with $20 \mathrm{U} / \mathrm{ml}$ trypsin (Invitrogen) in HBSS (Invitrogen) at $37^{\circ} \mathrm{C}$ for $12 \mathrm{~min}$. The tissue segments were then transferred to Neurobasal medium (Invitrogen) with 10\% heat-inactivated horse serum (Invitrogen), triturated with a fire-polished Pasteur pipette, and plated at $10^{5}$ cells per $12 \mathrm{~mm}$ glass coverslip coated with poly-D-lysine (>300 kDa; Sigma). Subsequent feeding occurred twice weekly, each time replacing half the volume with fresh Neurobasal media with $2 \%$ B-27 (Invitrogen). The cultures were maintained in a humidified tissue culture incubator with $5 \% \mathrm{CO}_{2}$ and taken for use after 15-17 d. Cultures were transfected using the calcium-phosphate method (Goetze et al., 2004 ) on days 7-8. Hippocampal mouse cultures from mice lacking the $\alpha 7-\mathrm{nAChR}$ gene [ $\alpha 7$ knock-outs; $(\alpha 7 \mathrm{KO})]$ mice were prepared in the same way from $\mathrm{P} 0-\mathrm{P} 1$ animals.

Immunocytochemistry. For immunostaining of surface GluA1-containing AMPA receptors (GluA1s) and surface HA- $\alpha 7-n A C h R s$, hippocampal neurons in culture were incubated with an extracellular GluA1 Ab (1:50; Calbiochem) and anti-HA Ab (1:100; Santa Cruz Biotechnology), respectively, for $30 \mathrm{~min}$ at $4^{\circ} \mathrm{C}$ in PBS plus $5 \%$ donkey serum. For immunostaining of intracellular proteins, cultures were fixed with $2 \%$ paraformaldehyde (PFA) in PBS for $10 \mathrm{~min}$ at room temperature (RT). After three washes with PBS, cells were permeabilized by incubating 10 min with $0.1 \%$ Triton X-100 in PBS. To label synapsin, ELKS, and the vesicular glutamate transporter (VGluT), neurons were incubated with an anti-synapsin 1,2 Ab (1:1000; Synaptic Systems), anti-ELKS Ab (1: 500; Synaptic Systems), or VGluT Ab (1:500; Synaptic Systems), respectively, for $1 \mathrm{~h}$ at RT in PBS containing 5\% normal donkey serum. After washing three times in PBS, cells were incubated with appropriate donkey FITC-, Cy3-, or Cy5-conjugated secondary Ab 2 h at RT (1:250; Jackson ImmunoResearch), washed three times with PBS, and mounted on slides for imaging.

To crosslink $\alpha 7-\mathrm{nAChRs}$, cells were incubated first with $100 \mathrm{~nm}$ biotinylated $\alpha$-bungarotoxin (Biot-Bgt) for $1 \mathrm{~h}$ to bind to the receptors, rinsed and then incubated with anti-biotin $\mathrm{Ab}(1 \mu \mathrm{g} / \mu \mathrm{l}$ for $10 \mathrm{~min})$, and then rinsed and incubated with secondary $\mathrm{Ab}(2.5 \mu \mathrm{g} / \mu \mathrm{l}$ for $10 \mathrm{~min})$. Controls substituted non-immune IgG for the primary Ab. All incubations were performed in Neurobasal medium at $37^{\circ} \mathrm{C}$. To visualize surface $\alpha 7$-nAChRs after crosslinking, an Alexa Fluor 488-labeled Ab was
A

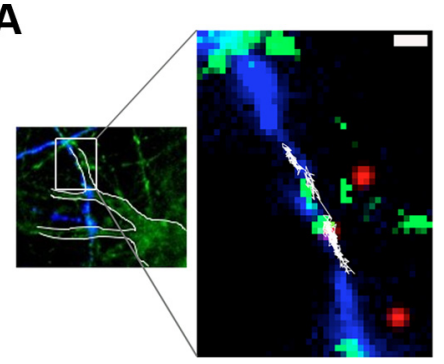

B

C

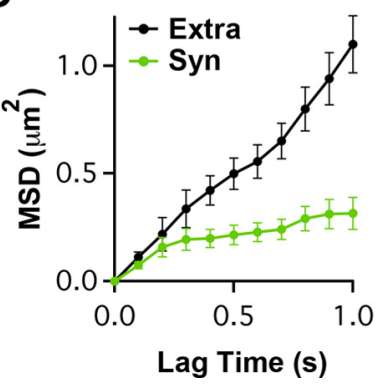

D

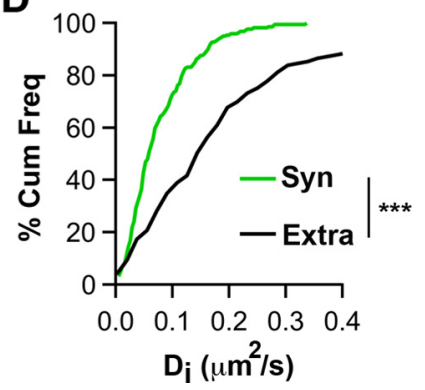

Figure 1. QD tracking indicates that presynaptic $\alpha 7-n A C h R s$ are constrained within synaptic space. $\boldsymbol{A}$, Left, Hippocampal neurons in culture stained with Mitotracker (green) and transfected with Sph-GFP (blue). Neuronal contours (white boundaries) and transfected axonal trajectories were visualized by saturating the Mitotracker and Sph-GFP images, respectively. Right, Higher magnification of the left inset (white box) showing an $\alpha 7-n A C h R-Q D$ complex (red) diffusing (white trajectory) on the membrane of an axon transfected with Sph-GFP (blue) and accessing synapses labeled with Mitotracker (green). Scale bar, $1 \mu \mathrm{m}$. $\boldsymbol{B}$, Representative example showing the variation in $D_{\mathrm{i}}$ for the $\alpha 7-\mathrm{nAChR}-\mathrm{QD}$ in $\boldsymbol{A}$ as a function of time. Horizontal line indicates time in synaptic (green) and extrasynaptic (black) spaces. C, Representative example of MSD versus lag time for $\alpha 7-n A C h R-Q D$ complexes in extrasynaptic (Extra) and synaptic (Syn) locations. The linear increase in MSD with time indicates free diffusion outside synapses, whereas the curved MSD with time inside synapses indicates confined diffusion. $\boldsymbol{D}$, Cumulative distribution of $D_{\mathrm{i}}$ values for synaptic and extrasynaptic $\alpha 7-n A C h R-Q D(n=118$ and 149 for synaptic and extrasynaptic trajectories, respectively, from $\geq 3$ independent culture sets for each condition; Mann-Whitney test, ${ }^{* * *} p<0.001$ ).

used as the secondary $(2.5 \mu \mathrm{g} / \mu \mathrm{l}$ for $10 \mathrm{~min}$ ). Controls (no crosslinking) used a Alexa Fluor 488-labeled anti-biotin $\mathrm{Ab}(1 \mu \mathrm{g} / \mu \mathrm{l}$ for $10 \mathrm{~min})$ and no secondary Ab.

To label the recycling pool of synaptic vesicles, neuronal cultures were incubated for $45 \mathrm{~s}$ with $5 \mu \mathrm{M}$ FM4-64FX [fixable version of $\mathrm{N}$-(3triethylammoniumpropyl)-4-(4-(dibutylamino)styryl) pyridinium dibromide; Invitrogen] in HEPES buffer containing $60 \mathrm{~mm} \mathrm{KCl}$. After washing three times with HEPES buffer containing $4 \mathrm{~mm} \mathrm{KCl}$, neurons were fixed with $2 \%$ PFA for $10 \mathrm{~min}$ at RT. To label the lumenal domain of synaptotagmin (Syn-Lum), cells were incubated with anti-synaptotagmin $\mathrm{Ab}$ (1:100; Synaptic Systems) for $5 \mathrm{~min}$ at $37^{\circ} \mathrm{C}$ in culture media as described previously (Biederer and Scheiffele, 2007). Neurons were fixed and permeabilized as above. Destaining of FM4-64FX dye was achieved by perfusing labeled neurons with PBS containing $40 \mathrm{~mm} \mathrm{~K}^{+}$while imaging at $5 \mathrm{~Hz}$ (see below).

Confocal images were acquired in sequential mode using a Leica SP5 confocal microscope with settings that did not saturate the fluorescence signals and that fulfilled Nyquist sampling criteria. NIH ImageJ software was used for quantifying the number of specific protein clusters. Four regions of interest (ROIs) of $20 \mu \mathrm{m}$ in length were randomly selected per field of view along the dendrites of neurons. ROIs were binarized automatically using the mean of the background value inside the dendrite plus three times the SD as an intensity threshold value for defining a cluster or puncta in each image. Clusters (puncta) within an ROI were counted if they had at least $3 \times 3$ pixels above threshold (pixel diameter, $80 \mathrm{~nm}$ ). Data are expressed as the mean \pm SEM per dendritic length of 20 $\mu \mathrm{m}$ and represent at least 10 images from each of three or more cultures.

Postsynaptic HA- $\alpha 7-\mathrm{nAChRs}$ were identified in transfected $\alpha 7 \mathrm{KO}$ neuronal cultures as those receptors located on a major dendrite ema- 
nating from a nearby transfected cell body. Presynaptic HA- $\alpha 7-n$ AChRs were identified as those receptors present on thin neurites (putative axons) far from transfected cell bodies and often found to cross untransfected dendrites as visualized with brightfield microscopy.

Calcium imaging. Crosslinking of $\alpha 7-$ nAChRs was performed as described above. Calcium imaging was performed as described previously (Gómez-Varela et al., 2012).

SPT. Labeling of surface $\alpha 7-\mathrm{nAChRs}$ with QD nanocrystals, acquisition, and analysis of the trajectories were performed as described previously (Gómez-Varela et al., 2012). Briefly, labeling of surface GluA1s with QD nanocrystals was achieved by first incubating neuronal cultures with $0.5 \mu \mathrm{g} / \mathrm{ml}$ anti-GluAl rabbit $\mathrm{Ab}$ (Calbiochem; PC246; recognizes the extracellular N-terminus domain) in PBS plus $0.1 \%$ $\mathrm{BSA}$ for $10 \mathrm{~min}$ at $37^{\circ} \mathrm{C}$. The neurons were then rinsed five times with PBS and incubated with 500 pм QD 605 goat $F\left(\mathrm{ab}^{\prime}\right) 2$ anti-rabbit IgG conjugate (heavy and light chain; Invitrogen) in PBS plus $0.1 \%$ BSA for $1 \mathrm{~min}$ at RT. The neurons were then rinsed five more times with PBS before imaging. Negative controls included substituting nonspecific IgG for the GluA1 Ab or incubating the neurons directly with QD 605 goat $\mathrm{F}\left(\mathrm{ab}^{\prime}\right) 2$ anti-rabbit IgG conjugate. No QD signal was detected in these negative controls. All trajectories analyzed in the SPT experiments were obtained from at least four independent hippocampal culture platings.

Electrophysiology. Hippocampal cultures were immersed in artificial CSF (aCSF; in mM: $150 \mathrm{NaCl}_{2}, 5 \mathrm{KCl}, 2 \mathrm{CaCl}_{2}, 1 \mathrm{MgCl}_{2}, 10$ glucose, and 10 HEPES) and placed in a recording chamber mounted on a Zeiss Axiovert. Patch pipettes $(2.0-4.0 \mathrm{M} \Omega)$ were visually guided to the surface of individual neurons. Patch pipettes contained the following (in $\mathrm{mM}$ ): 125 K-gluconate, $15 \mathrm{KCl}, 8 \mathrm{NaCl}_{2}$, 2 EGTA, $10 \mathrm{Na}_{2}$ phosphocreatine, $4 \mathrm{Mg}$-ATP, $0.3 \mathrm{Na}-\mathrm{GTP}$, and 10 HEPES, $\mathrm{pH}$ 7.25. Voltage-clamp recordings were obtained with an Axopatch 200A and Clampex 8.2 software (Molecular Devices). Data were acquired at $5 \mathrm{kHz}$ and filtered at $2 \mathrm{kHz}$. Pipette capacitance was canceled, whole-cell capacitance was neutralized, and series resistance was compensated by $80 \%$ in all recordings. All activity was recorded at $-70 \mathrm{mV}$.

To record glutamatergic mEPSCs, $1 \mu \mathrm{M}$ tetrodotoxin (TTX) and $20 \mu \mathrm{M}$ gabazine were included in the recording medium. Mini Analysis software was used to detect the mEPSCs, with an amplitude threshold of four times the SD of the mean background noise level. All detected events were verified by visual inspection.

To assay the size of the RRP, neurons patch clamped in the presence of $1 \mu \mathrm{M}$ TTX were subjected to hyperosmotic shock (Rosenmund and Stevens, 1996). Briefly, a $4 \mathrm{~s}$ application of aCSF containing $0.5 \mathrm{~m}$ sucrose and $1 \mu \mathrm{M}$ TTX was ejected from a multibarrel pipette positioned $30 \mu \mathrm{m}$ away from the cell body of the patched neuron. The sucrose-containing solution was applied from the central barrel, which was surrounded by barrels ejecting extracellular media at the same flux speed. The time needed to change between barrels was 5-7 ms. This configuration ensured a rapid application and washing of the sucrose solution. To study the refill properties of the RRP, a 4 s pulse of sucrose was applied a second

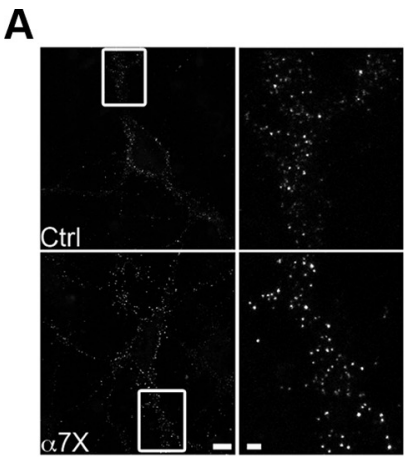

C

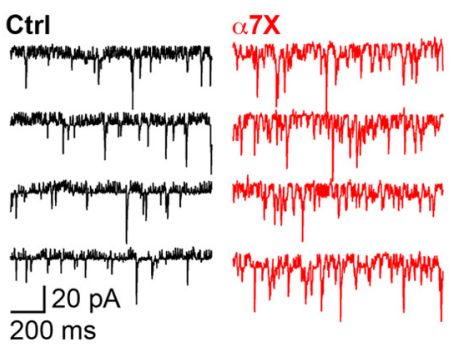

E

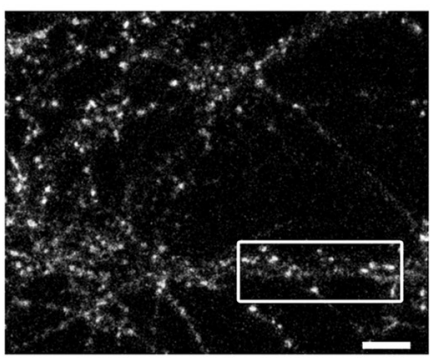

B

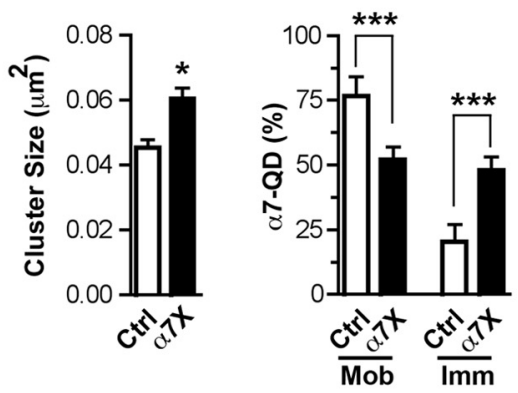

Figure 2. Reducing $\alpha 7-n A C h R$ mobility increases synaptic transmission. $\boldsymbol{A}$, Left, Representative images showing $\alpha 7-n A C h R$ staining in control (Ctrl) or crosslinked $(\alpha 7 \mathrm{X})$ conditions. Middle, Higher magnification of the left insets (white boxes). Scale bars, 10 and $2 \mu \mathrm{m}$. Right, Quantification of $\alpha 7-\mathrm{nAChR}$ cluster size for Ctrl and $\alpha 7 \mathrm{X}(n=22$ neurons, 4 culture sets; mean \pm SEM ( 16 neurons, 4 culture sets; mean \pm SEM; Student's $t$ test, $\left.{ }^{* *} p<0.01\right)$. $\boldsymbol{E}$, Left, Image shows synapsin , top), surface GluA1 staining (Surf GluA1, middle), and overlay of the two (Merge, bottom; Synap, green; GluA1, red). of synaptic number (colocalized Synap and GluA1 puncta) for Ctrl and $\alpha 7 \mathrm{X}$ ( $n=19$ neurons, 4 culture sets for both $\mathrm{Ctrl}$ and $\alpha 7 \mathrm{X}$ mean \pm SEM; Student's $t$ test, $p>0.05$ ).

and third time at $30 \mathrm{~s}$ intervals. Total charge was calculated by integrating the area of the response after each application using Clampfit 8.2 software.

\section{Results}

Presynaptic $\alpha 7-n A C h R s$ are constrained in synaptic space To examine the mobility of presynaptic $\alpha 7-n A C h R s$, we used SPT with QDs. Hippocampal neurons in culture were incubated first with Biot-Bgt to label $\alpha 7-\mathrm{nAChRs}$ and then with streptavidin-QD to attach the fluorescent nanocrystal to the bound Biot-Bgt. To distinguish QD-tagged presynaptic $\alpha 7-\mathrm{nAChRs}$, axons were marked by sparsely transfecting the cultures 7-9 d earlier with Sph-GFP. Incubating with a low concentration of a rhodamine-derivative mitochondrial marker (Mitotracker) indi- 
A

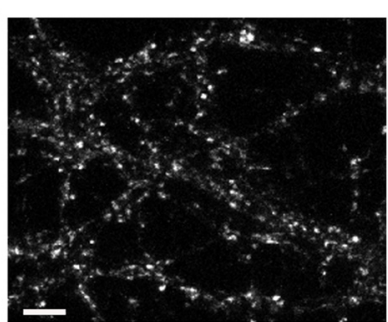

B

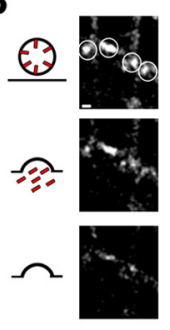

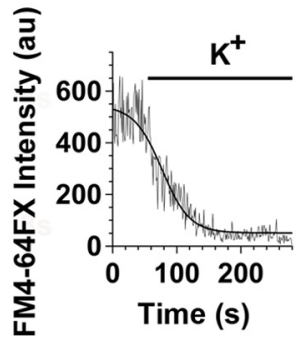

D
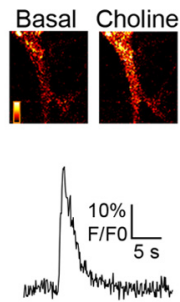

C

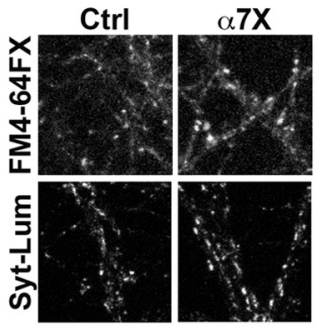

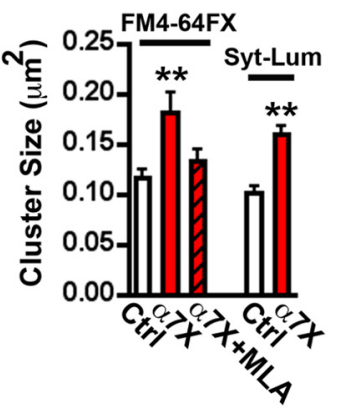

Figure 3. Reducing the mobility of $\alpha 7-n A C h R s$ increases the pool size of recycling vesicles. $A$, Representative image of FM464FX staining in hippocampal cultures. Scale bar, $5 \mu \mathrm{m}$. B, Left, Representative image of a presynaptic terminal at various times after stimulation with $\mathrm{KCl}$. Right, Trace showing a representative destaining time course following a sigmoidal kinetic (solid line) in arbitrary units (au). C, Left, Representative images of FM4-64FX and Syn-Lum staining in control (Ctrl) and crosslinked ( $\alpha 7 \mathrm{X})$ conditions. Right, Quantification of FM4-64FX cluster size in Ctrl, $\alpha 7 X$, and $\alpha 7$ X plus MLA, or Syt-Lum cluster size in Ctrl and $\alpha 7 X$ ( $n=21-24$ neurons from $4-5$ culture sets for each condition; mean \pm SEM; one-way ANOVA, $\left.{ }^{* *} p<0.01\right)$. D, Top, Representative fluorescent images of a dendrite loaded with the calcium fluor Fluo-4 captured before (Basal) and after (Choline) puffing on choline. Bottom trace shows a representative time course for the decay of the fluorescent signal after $\alpha 7-\mathrm{nAChR}$ activation by choline.

cated synaptic sites along the axon (Fig. 1A). This enabled us to select QD-labeled $\alpha 7-\mathrm{nAChRs}$ confined to axons and distinguish those moving into and out of synaptic spaces (Tardin et al., 2003; Groc et al., 2004; Ehlers et al., 2007). The dynamics of such QDlabeled $\alpha 7-$ nAChRs were followed over a 60 s period with $\sim 50$ nm accuracy (see Materials and Methods). The instantaneous diffusion coefficient $\left(D_{\mathrm{i}}\right)$, calculated as a function of time, showed that the receptors displayed either low or high mobility, depending on their being in either synaptic or extrasynaptic space, respectively (Fig. $1 B$ ). The mean square displacement (MSD) of the trajectory was consistent with Brownian diffusion outside synapses but indicated confined movement within presynaptic terminals (Fig. $1 C$ ). Cumulative frequency plots display the consistent differences in $D_{\mathrm{i}}$ values depending on receptor location (Fig. 1D). Notably, the SPT analysis indicates that extrasynaptic $\alpha 7-\mathrm{nAChRs}$ on axons diffuse more rapidly than on dendrites [median $\pm 25-75 \%$ interquartile range (IQR), $0.21 \pm 0.08-0.26$ vs $0.165 \pm 0.095-0.20$ for presynaptic vs postsynaptic $\alpha 7-\mathrm{nAChR}-\mathrm{QD}$ complexes; $p<0.001$, Mann-Whitney test; $n=149,60$ trajectories; Gómez-Varela et al., 2012]. The results demonstrate that surface $\alpha 7-\mathrm{nAChRs}$ are mobile on axon terminals but constrained within synaptic space.

\section{Decreasing the mobility of presynaptic $\alpha 7-n A C h R s$ increases glutamate release}

To test the functional relevance of presynaptic $\alpha 7-n A C h R$ lateral mobility, we measured transmitter release after additional restraining $\alpha 7-\mathrm{nAChR}$ movement using Biot-Bgt/Ab crosslinking (Heine et al., 2008; see Materials and Methods). As expected, the crosslinking procedure increased the mean size of $\alpha 7-\mathrm{nAChR}$ clusters on the dendritic surface (Fig. 2A) and decreased $\alpha 7-$

nAChR mobility (Fig. 2B). We assessed effects on glutamate release first by patchclamp recording of mEPSCs in the presence of TTX to block action potentials and gabazine to block GABAergic responses. Remarkably, the Ab crosslinking of $\alpha 7-\mathrm{nAChRs}$ significantly increased the frequency of mEPSCs more than twofold ( $\alpha 7 \mathrm{X}$ in Fig. $2 C, D$ ). Neither the mean amplitude nor decay kinetics of the mEPSCs were changed by the crosslinking. These findings are compatible with greater release at preexisting synapses or possibly with an increase in the number of synapses. To exclude the latter possibility, we quantified the number of synaptic sites as revealed by colocalization of the presynaptic marker synapsin-1,2 with the postsynaptic marker GluA1. No increases were seen in either the colocalization of GluA1 with synapsin (Fig. 2E) or their puncta number (data not shown) when $\alpha 7-\mathrm{nAChRs}$ were crosslinked. This argues against the increase in mEPSC frequency representing an increase in synapse number.

In contrast, crosslinking did affect release capability as monitored by uptake of the dye FM4-64FX, which can be used to label recycling vesicle pools (Pyle et al., 2000; Südhof, 2000). Stimulation of FM464FX-labeled terminals depletes the accumulated dye, consistent with its having been in recycling vesicles (Fig. $3 A, B$ ). Crosslinking $\alpha 7-$ nAChRs increased the size of FM464FX-labeled clusters in terminals after potassium-induced vesicle release and re-endocytosis (Fig. 3C). The same result was obtained using a Syn-Lum Ab (Fig. 3C) that recognizes an intravesicular epitope (Biederer and Scheiffele, 2007). Importantly, the effect of crosslinking $\alpha 7-\mathrm{nAChRs}$ on transmitter release appears to require functional $\alpha 7-n A C h R s$. This was found by repeating the $\alpha 7-\mathrm{nAChR}$ crosslinking experiment in the presence of the $\alpha 7-\mathrm{nAChR}$-specific antagonist methyllycaconitine (MLA) during both the $\mathrm{Ab}$ incubation and the potassium pulse used for FM4-64FX labeling. MLA prevented the increase in labeling otherwise seen after crosslinking presynaptic $\alpha 7-\mathrm{nAChRs}$ (Fig. $3 C$ ). Direct evidence that a fraction of the $\alpha 7-n A C h R s$ remain functional after crosslinking was obtained by challenging them with choline while using a calcium fluor to report depolarizationinduced calcium increases (Fig. 3D) as described previously (Gómez-Varela et al., 2012). Receptor crosslinking did not increase the number of FM4-64FX-labeled terminals (data not shown), and MLA treatment in the absence of crosslinking had no effect on transmitter release (FM4-64FX cluster size, $0.10 \pm$ 0.02 vs $0.12 \pm 0.03 \mu \mathrm{m}^{2}$ for control and MLA, respectively). The results are consistent with the crosslinking causing an increase in the capacity for synaptic vesicle release at existing synapses. The effect was specific for $\alpha 7-n A C h R s ; A b$ crosslinking of mobile presynaptic cannabinoid $1 \mathrm{~b}$ receptors (CB1; Mikasova et al., 2008) did not change FM4-64FX uptake compared with controls (FM4-64FX cluster size, $0.13 \pm 0.03$ vs $0.11 \pm 0.02 \mu \mathrm{m}^{2}$ for control and CB1 crosslink, respectively).

To confirm that presynaptic, and not postsynaptic, $\alpha 7$ nAChRs were responsible for the increased transmitter release, 
we repeated the experiments with dissociated hippocampal cell cultures prepared from $\alpha 7 \mathrm{KO}$. The $\alpha 7 \mathrm{KO}$ cells were sparsely transfected in culture with a construct encoding HA-tagged $\alpha 7-\mathrm{nAChR}$, enabling the receptors to be labeled and crosslinked using an anti-HA Ab to an extracellular epitope. Crosslinking presynaptic HA- $\alpha 7-n A C h R s$ in this manner did increase release, as monitored by increased labeling by Syn-Lum (Fig. $4 A, C$ ). Crosslinking postsynaptic HA- $\alpha 7-$ nAChRs had no effect (Fig. $4 B, C$ ). Control experiments were performed to show that mouse hippocampal cultures behaved like the rat cultures described above with respect to $\alpha 7-$ nAChR crosslinking, causing increased Syn-Lum labeling (Fig. 4C). The results demonstrate that reducing the mobility of presynaptic $\alpha 7-$ nAChRs enhances spontaneous transmitter release by increasing release at existing synapses.

Immobilizing presynaptic $\alpha 7-n A C h R s$ enhances transmitter release by increasing the RRP

The increase in mEPSC frequency, together with the increase in size of both FM4-64FX puncta and Syn-Lum puncta, suggests that immobilizing presynaptic $\alpha 7-n A C h R s$ by crosslinking increases the release capability of presynaptic terminals. This could result from either an increase in the size of the RRP or an increase in the kinetics of synaptic vesicle release and recycling. To resolve this, we quantified the RRP by stimulating terminals with a $4 \mathrm{~s}$ application of hypertonic sucrose while recording the total evoked EPSC in postsynaptic neurons. Crosslinking $\alpha 7-\mathrm{nAChRs}$ increased the initial phase of the response $(0-2 \mathrm{~s})$, which is proportional to RRP size (Fig. $5 A)$. It had no effect on the second phase of the response (2-4 s), which reflects ongoing exocytosis of vesicles and RRP refilling (Fig. 5A; Rosenmund and Stevens, 1996; Deng et al., 2011). No change occurred in the kinetics of sucrose-induced release analyzed by quantifying cumulative charge transfer (Fig. 5B). The refilling dynamics of the RRP was also unaffected. This was determined by measuring the response (total charge transfer in the postsynaptic cell) to three successive applications of hypertonic sucrose $30 \mathrm{~s}$ apart (Fig. 5C; Deng et al., 2011). The fact that crosslinking of $\alpha 7-n A C h R s$ increased RRP size without affecting either the rate of release or the refilling of the RRP suggests a role for specific active zone scaffold proteins linking $\alpha 7-\mathrm{nAChRs}$ to latent transmitter release sites.

\section{The degree of $\alpha 7-n A C h R$ mobility has downstream consequences for AMPA trafficking}

Silencing of transmitter release increases the mobility of postsynaptic AMPA receptors (Ehlers et al., 2007); increasing the amount of release can have the opposite effect (Heine et al., 2008; Opazo et al., 2010). To determine whether the increases in transmitter release caused by reducing $\alpha 7-\mathrm{nAChR}$ mobility was likely to be physiologically significant, we examined a potential downstream effect, namely the effect on postsynaptic AMPA receptor mobility. SPT with QDs was used to track the mobility of endogenous GluA1s on neurons in hippocampal cultures. Crosslinking of $\alpha 7-$ nAChRs clearly decreased the proportion of GluA1s that was mobile and, correspondingly, increased the proportion that scored as immobile (Fig. 6A). No change was seen in the rates of diffusion for the remaining mobile GluA1s after $\alpha 7-\mathrm{nAChR}$ crosslinking (Fig. 6B), but there was a significant increase in the dwell time of the receptors in synaptic space (Fig. $6 C$ ). The results are consistent with immobilization of presynaptic $\alpha 7-\mathrm{nAChRs}$ causing enhanced transmitter release sufficient to exert transynaptic effects, in this case altering the trafficking of postsynaptic AMPA receptors. Therefore, presynaptic $\alpha 7-\mathrm{nAChR}$ mobility may not only have local effects on transmitter release
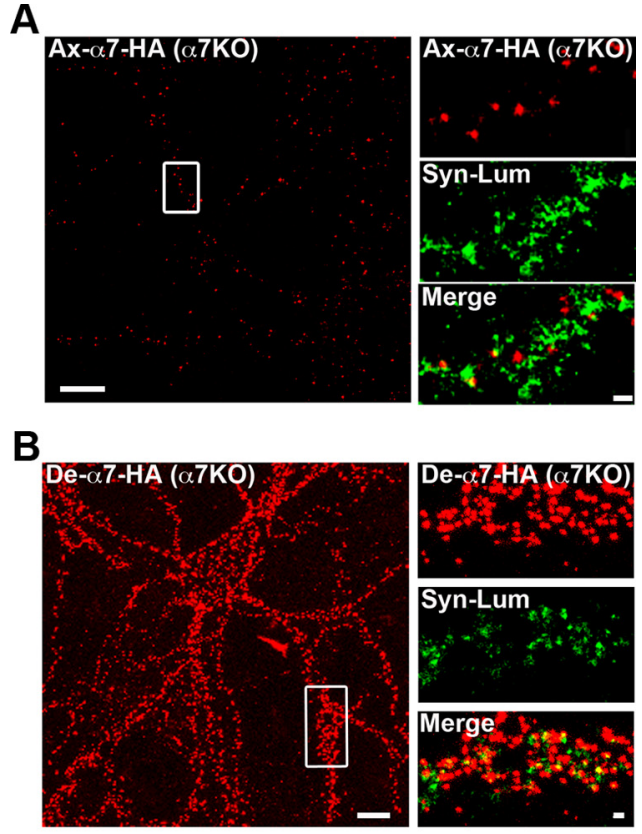

C

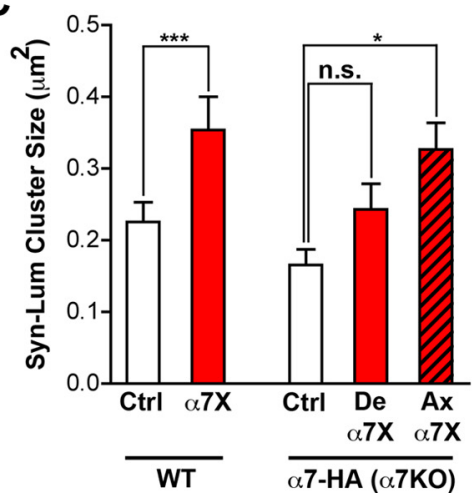

Figure 4. Crosslinking presynaptic $\alpha 7-n A C h R s$ increases synaptic transmission. $\boldsymbol{A}$, Left, Representative image of a transfected $\alpha 7 \mathrm{KO}$ hippocampal neuron in culture expressing $\mathrm{HA}-$ $\alpha 7-n A C h R$ on an axon (Ax- $\alpha 7$-HA; boxed region). Scale bar, $10 \mu \mathrm{m}$. Right, Magnified images of the boxed region showing $H A-\alpha 7-n A C h R$ staining (red, top), Syn-Lum staining (green, middle), and the two merged (Merge, bottom). Scale bar, $1 \mu \mathrm{m}$. B, Left, Representative image of a transfected $\alpha 7 \mathrm{~K} 0$ neuron expressing $\mathrm{HA}-\alpha 7-n A C h R$ on dendrites (De- $\alpha 7$-HA). Scale bar, $10 \mu \mathrm{m}$. Right, Magnified image of the boxed region showing HA- $\alpha 7-n A C h R$, Syn-Lum, and the two merged as in $\boldsymbol{A}$. Scale bar, $1 \mu \mathrm{m}$. C, Left, Quantification of Syn-Lum puncta size in control (Ctrl) and crosslinked ( $\alpha 7 \mathrm{X})$ conditions in wild-type mouse hippocampal neurons in culture ( $n=14$ neurons from 3 culture sets for both conditions; mean \pm SEM; Student's $t$ test, $\left.{ }^{* * *} p<0.001\right)$. Right, Syn-Lum puncta size in $\alpha 7 K 0$ mouse hippocampal neurons in controls (Ctrl), after crosslinking dendritic HA- $\alpha$ 7-nAChRs (De $\alpha 7 \mathrm{X}$ ), or after crosslinking axonal HA$\alpha 7-n A C h R s$ ( $A x \alpha 7 X ; n=12$ neurons from 3 culture sets for each condition; mean \pm SEM; one-way ANOVA, $\left.{ }^{*} p<0.05\right)$.

but may also exert more extensive changes through downstream signaling.

\section{Synapse-specific blockade of transmitter release further} constrains presynaptic $\alpha 7-$ nAChRs

If constraining presynaptic $\alpha 7-\mathrm{nAChRs}$ at synaptic sites enables nerve terminals to increase transmitter release, one might predict that blockade of release would induce a homeostatic response in the terminal that further restrained $\alpha 7-\mathrm{nAChRs}$ at that site in an attempt to restore release capability. To test this, we transfected neurons with TeT/Sph-GFP. In neurons expressing the construct, TeT cleaves vesicle-associated membrane protein 2, 
A

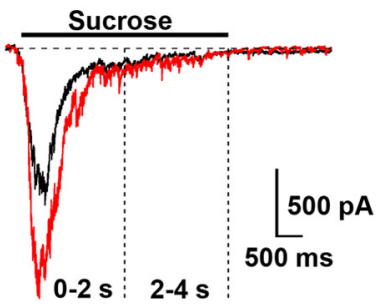

B

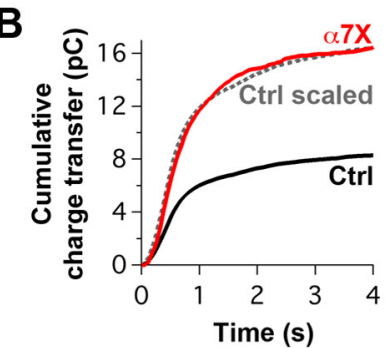

C

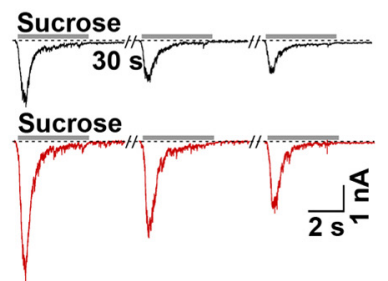

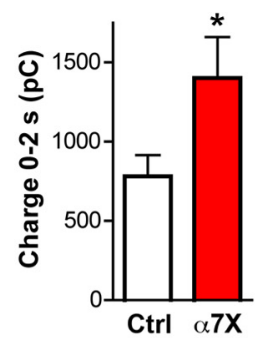
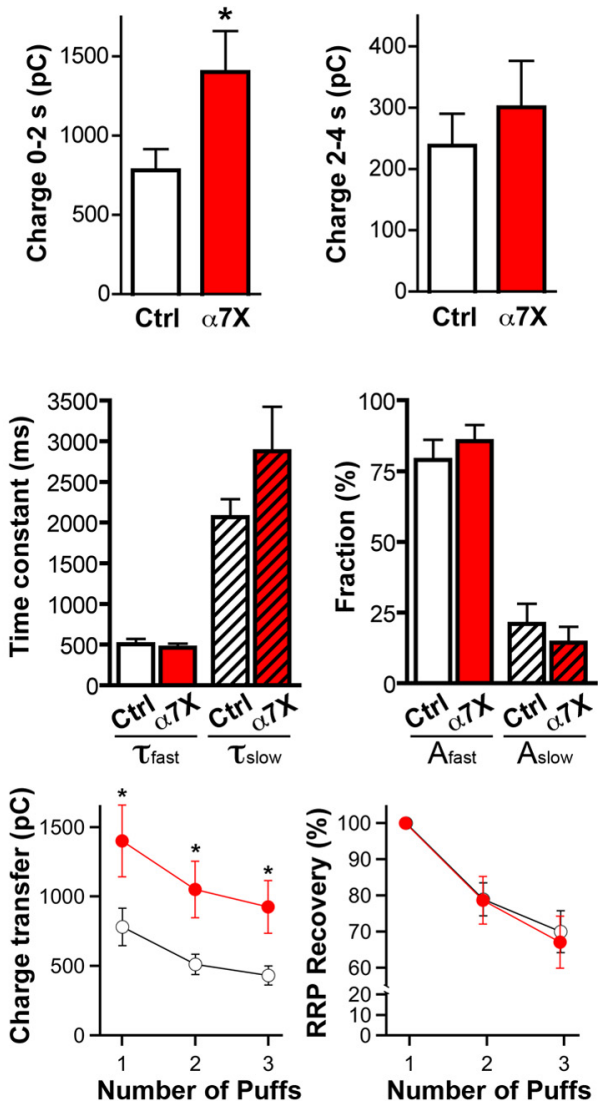

Figure 5. Effects of $\alpha 7-n A C h R$ crosslink on RRP capacity and kinetics. $\boldsymbol{A}$, Sample traces (left) and summary charge-transfer graphs (right) of EPSCs induced by hypertonic sucrose $(0.5 \mathrm{~m})$ in control (Ctrl, black trace) and crosslinked $\alpha 7-n A C h R$ ( $\alpha 7 \mathrm{X}$, red trace) conditions. Hypertonic sucrose was puffed using a multibarrel pipette (see Materials and Methods) onto the patched neuron for $4 \mathrm{~s}$ in the presence of $1 \mu \mathrm{m}$ TTX and $50 \mu \mathrm{m}$ gabazine. Charge transfer during the initial (Charge $0-2 \mathrm{~s}$ ) and steady-state responses (Charge $2-4$ s) were quantified to estimate the RRP size ( $n=17$ neurons, 4 culture sets for both conditions; mean \pm SEM; Student's $t$ test, ${ }^{*} p<0.05$ ). $\boldsymbol{B}$, Cumulative charge transfer as a function of time (left) and the corresponding kinetic analyses (right) of sucrose-induced EPSCs in control (Ctrl, black) and crosslinked ( $\alpha 7 \mathrm{X}$, red) conditions. Dotted gray line shows the scaled control (Ctrl scaled) for comparison. The integrated charge transfer was fitted with a double-exponential function to determine kinetic parameters for the fast and slow components $\left(\tau_{\text {fast }}\right.$ and $\tau_{\text {slow, }}$ respectively) and for their amplitudes $\left(A_{\text {fast }}\right.$ and $\left.A_{\text {slow }}\right)$. C, Representative EPSC traces (left) and summary graphs (right) showing absolute and normalized data for RRP recovery over three sucrose applications at $30 \mathrm{~s}$ interpuff intervals in control (black) and crosslinked (red) conditions. RRP recovery was calculated by dividing the second and third sucrose-induced charge transfer by the value of the first and then normalized to the first current amplitude ( $n=19$ neurons, 4 culture sets for both conditions; mean \pm SEM; Student's $t$ test, ${ }^{*} p<0.05$ ).

thereby blocking transmitter release (Harms et al., 2005; Ehlers et al., 2007). $D_{\mathrm{i}}$ values calculated from MSD plots for $\alpha 7$-nAChRs on neurons showed that TeT/Sph-GFP expression lowered the mobility of axonal $\alpha 7-n A C h R s$ specifically at synaptic sites and not at extrasynaptic sites (Fig. 7A). TeT/Sph-GFP expression also significantly increased the dwell time of $\alpha 7-n A C h R s$ on the axon that enter synaptic space (Fig. $7 B$ ). The results demonstrate that the constraint of surface $\alpha 7-\mathrm{nAChRs}$ within synaptic space is increased when transmitter release is compromised by TeT.

\section{CAST/ELKS is a candidate mediator of $\alpha 7-n A C h R$ mobility effects on glutamate release}

To enhance RRP size, presynaptic $\alpha 7-n A C h R s$ presumably must be linked to the presynaptic scaffold, positioning the receptors to augment release. To identify candidate proteins tethering $\alpha 7-$ nAChRs to presynaptic release machinery, we performed an unbiased proteomic screen from rat brain extracts. Bgt linked to Actigel beads was used to purify $\alpha 7-$ nAChRs and associated proteins (Gómez-Varela et al., 2012). Negative controls included unlinked beads, inclusion of the competitor nicotine along with the Bgt beads, and soluble Bgt with the Bgt beads, as described previously (Gómez-Varela et al., 2012). Proteins specifically bound to $\alpha 7-$ nAChRs were identified by comparative liquid chromatography-tandem mass spectrometry analysis of the eluates to determine which were uniquely associated with Bgt beads. Interestingly, the procedure revealed three specific peptides belonging to CAST/ ELKS in eluates from Bgt beads (data not shown). ELKS - also known as Rab6interacting proteins, CASTs, and ERCsare central components of the presynaptic active zone with proposed roles in transmitter release (Kaeser et al., 2009; Südhof, 2012). The "bait protein" $\alpha 7-\mathrm{nAChR}$ was found only in the Bgt-bead eluate (data not shown), consistent with specificity.

Because rat brain extracts include $\alpha 7$ nAChRs from multiple sources, we felt it necessary to target directly the presynaptic population. Presynaptic $\alpha 7-n$ AChRs cannot presently be uniquely distinguished by immunostaining. Accordingly, to visualize them specifically, we transfected $\alpha 7 \mathrm{KO}$ cultures with $\mathrm{HA}-\alpha 7-$ $\mathrm{nAChR}$ as above and confirmed that the receptors colocalize with ELKS on presynaptic terminals identified by an $\mathrm{Ab}$ against VGluT (Fig. $8 A$ ). The $\alpha 7 \mathrm{KO}$ cultures, with or without transfection, had VGluT and ELKS puncta equivalent in numbers to those found in wild-type cultures $(29.7 \pm$ 1.9 vs $30.9 \pm 2.3$ for VGluT and $37.3 \pm 3$ vs $32.6 \pm 3.4$ for ELKS on wild types and $\alpha 7 \mathrm{KOs}$, respectively), suggesting no deficit in the total number of glutamatergic synapses on $\alpha 7 \mathrm{KO}$ neurons in culture under these conditions. Notably, crosslinking $\alpha 7-\mathrm{nAChRs}$ increased the size of ELKS clusters and decreased the size of synaptophysin clusters on axons, consistent with the presynaptic $\alpha 7-$ nAChRs being closely positioned near release machinery (Fig. 8B).

RNAi was used to knockdown ELKS1 levels in neurons by transfecting them with a short-hairpin RNA directed against ELKS1 mRNA (E1-RNAi; Fig. 8C). The E1-RNAi construct, but not a scrambled control (Scr-RNAi), prevented the FM4-64FX increase in puncta size otherwise induced by presynaptic $\alpha 7-$ nAChR crosslinking (Fig. 8D). ELKS1 knockdown did not alter basal uptake by the terminal. The results are consistent with CAST2/ELKS1 being a contributor to the effects of presynaptic $\alpha 7-\mathrm{nAChRs}$ on glutamate release.

\section{Discussion}

The results demonstrate that calcium-permeable $\alpha 7-\mathrm{nAChRs}$ are mobile on the axon surface but are restrained at presynaptic release sites in which they can act to enhance transmitter release. Immobilizing the receptors further, such that they display increased dwell time in synaptic space, increases the release capability of the synapse. Conversely, the synaptic restraint is in- 
A
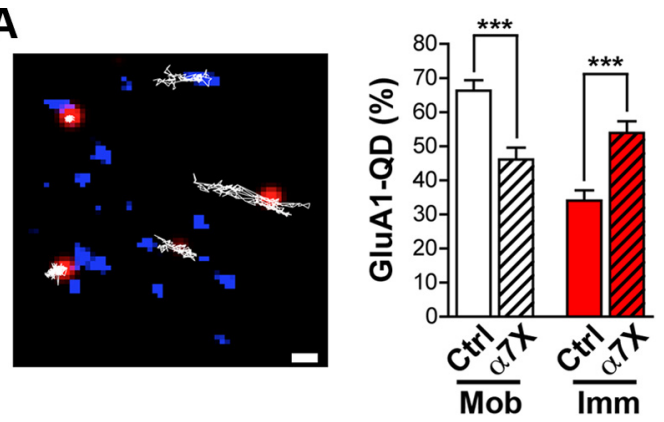

B

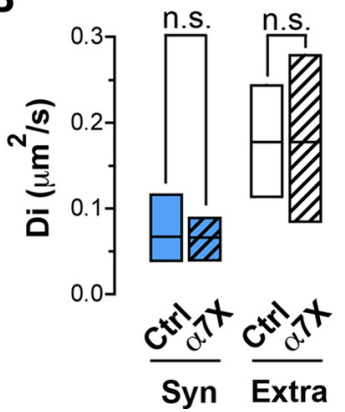

A

C

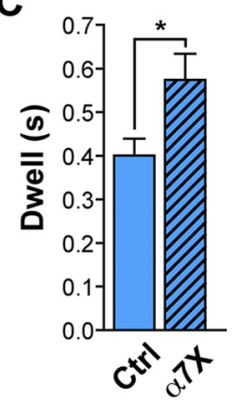

C

D

Figure 6. AMPA mobility is reduced after $\alpha 7-n A C h R$ crosslinking. $\boldsymbol{A}$, Left, Image shows synapses of hippocampal neurons in culture stained with Mitotracker (blue) and the trajectories (white lines) of mobile and immobile postsynaptic GluA1-QD complexes (red). Scale bar, $1 \mu \mathrm{m}$. Right, Quantification of mobile and immobile GluA1-QD complexes in control (Ctrl) and crosslinked $\alpha 7-\mathrm{nAChR}(\alpha 7 \mathrm{X})$ conditions ( $n=21$ and 36 images, 4 culture sets for both conditions; mean \pm SEM; Student's $t$ test, $\left.{ }^{* * *} p<0.001\right)$. $\boldsymbol{B}$, Median diffusion $\pm 25-75 \%$ IQR of GluA1-QD complexes in synaptic (Syn) and extrasynaptic (Extra) spaces in control and crosslinked conditions ( $n=78,138$ and 72, 63 for synaptic and extrasynaptic trajectories of Ctrl and $\alpha 7 X$ conditions, respectively, from 3 culture sets for each; Mann-Whitney test, $p>0.05)$. C, Synaptic dwell time of GluA1-QD complexes in control and crosslinked conditions ( $n=22$ and 16 QDs, 4 culture sets for each; mean \pm SEM; Student's $t$ test, ${ }^{*} p<0.05$ ).

A

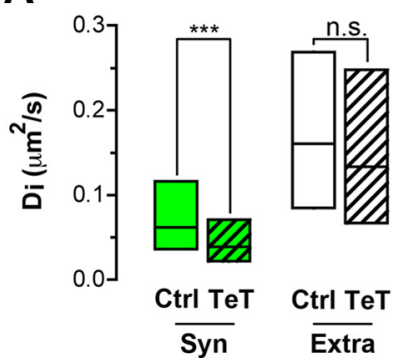

B

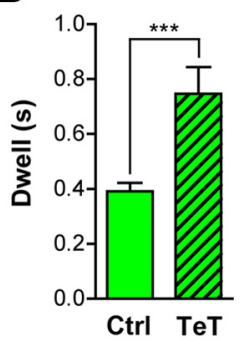

Figure 7. Silencing of transmitter release reduces $\alpha 7-n A C h R$ mobility inside presynaptic terminals. The mobility of $\alpha 7-n A C h R s$ on hippocampal neurons in culture was assessed with QDs as in Figure 1. Mobility on neurons with normal synaptic activity (transfected with SphGFP) was compared with those on neurons in which transmitter release was silenced (transfected with TeT/Sph-GFP). $A$, Median $D_{i} \pm 25-75 \%$ IQR of $\alpha 7-n A C h R-Q D$ complexes in synaptic (Syn) and extrasynaptic (Extra) spaces on neurons transfected with Sph-GFP (Ctrl) or TeT/Sph-GFP (TeT). Silencing of transmitter release significantly decreased the mobility of synaptic receptors specifically inside terminals ( $n=50,55$ and 118, 149 for synaptic and extrasynaptic trajectories of Ctrl and TeT conditions, 3 culture sets for each; Mann-Whitney test, $\left.{ }^{* * *} p<0.001\right)$. B , Synaptic silencing reduces the dwell time of $\alpha 7-\mathrm{nAChR}-\mathrm{QD}$ s inside terminals ( $n=12$ and 22 QDs from 3 culture sets for Ctrl and TeT, respectively; mean \pm SEM; Student's $t$ test, $\left.{ }^{* * *} p<0.001\right)$.

creased at the site when transmitter release is compromised. The mobility-dependent effects of $\alpha 7$-nAChRs on release represent changes in RRP size and may be mediated in part by ELKS1. The results suggest a regulatory mechanism in which $\alpha 7-\mathrm{nAChRs}$ are
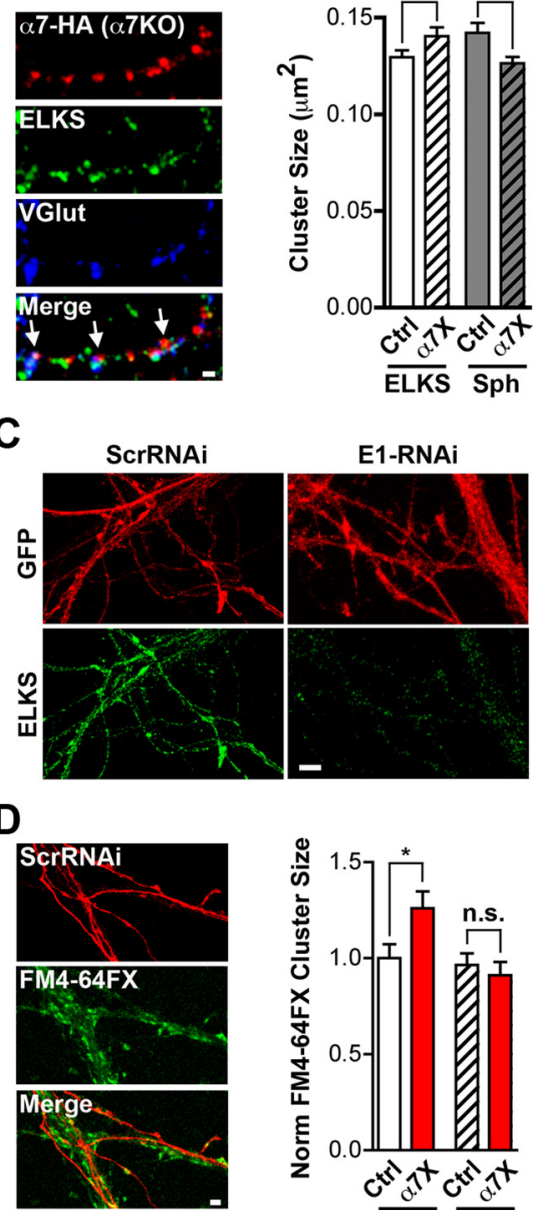

B
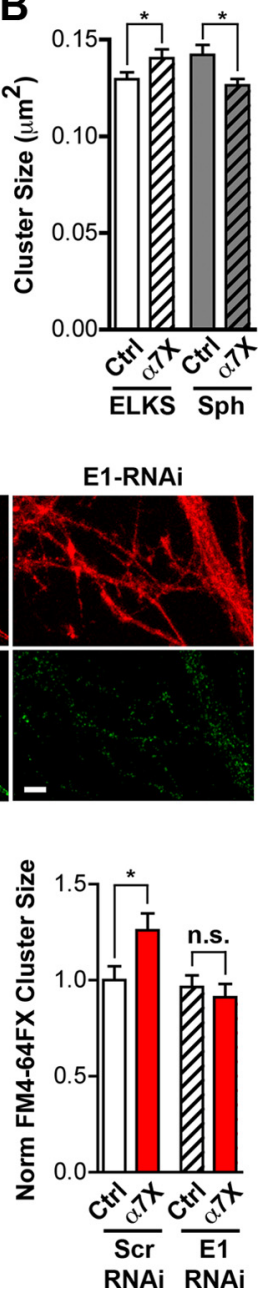

Figure 8. Functional proteomics suggests ELKS as a possible mediator of $\alpha 7-n A C h R$ crosslinking effects on release capacity. $\boldsymbol{A}$, Representative images of an axon from a transfected neuron expressing $\mathrm{HA}-\alpha 7-\mathrm{nAChR}$ (red), ELKS (green), and VGluT immunostaining (blue) and the three merged (Merge) with arrows indicating colocalization characteristic of presynaptic terminals. Scale bar, $1 \mu \mathrm{m}$. B, Quantification of ELKS and synaptophysin (Sph) cluster size on rat hippocampal neurons in culture under control (Ctrl) and crosslinked $\alpha 7-\mathrm{nAChR}(\alpha 7 \mathrm{X})$ conditions ( $n=27$ neurons, 4 culture sets per condition; mean \pm SEM; Student's $t$ test, ${ }^{*} p<0.05$ ). C, Representative images of neurons expressing GFP (red) and ELKS (green) after being infected with either control Scr-RNAi or E1-RNAi virus. Scale bar, $5 \mu \mathrm{m}$. D, Left, Representative images of cells expressing control Scr-RNAi (red), stained for FM4-64FX (green), and the images merged (Merge). Scale bar, $2 \mu \mathrm{m}$. Right, Quantification of FM4-64FX puncta size in Ctrl and $\alpha 7$ X cultures infected with either Scr-RNAi virus as control or E1-RNAi virus ( $n=25$ neurons, 4 culture sets per condition; mean \pm SEM; Student's $t$ test, ${ }^{*} p<0.05$ ).

recruited to and restrained at transmitter release sites as needed to promote transmitter release capability (Fig. 9).

SPT with QDs has been an effective technique for defining the mobility of postsynaptic membrane proteins (Triller and Choquet, 2008; Czöndör et al., 2012), including $\alpha 7-n A C h R s$ at both nicotinic (Fernandes et al., 2010) and glutamatergic (Gómez-Varela et al., 2012) synapses. Although numerous classes of ligand-gated ion channels are located presynaptically in which they can influence transmitter release (Dudel and Kuffler, 1961; Eccles, 1964; Khakh and Henderson, 2000; Langer, 2008; Duguid and Smart, 2009; Larsen et al., 2011), their diffusion properties have been less well characterized (Mikasova et al., 2008; Mercer et al., 2011). Here we show for the first time that $\alpha 7$-nAChRs are mobile on axon surfaces but are constrained in synaptic space. The mean $D_{\mathrm{i}}$ value obtained here for $\alpha 7$-nAChRs 
A

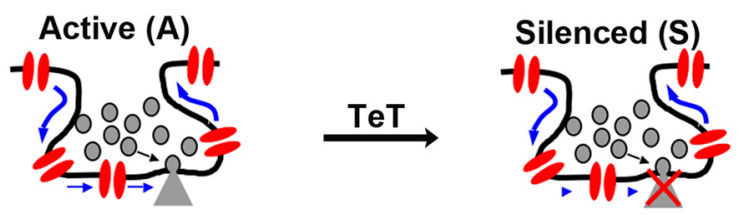

B
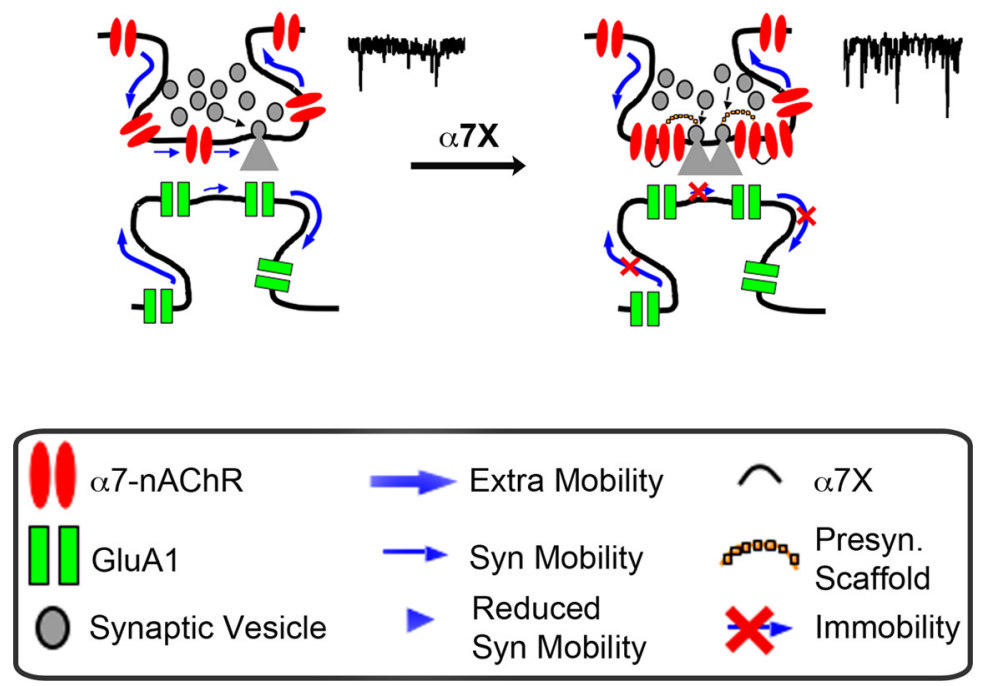

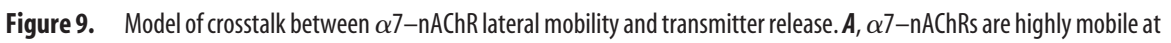
the axonal surface, exchanging between extrasynaptic and synaptic spaces. TeT impairs spontaneous release and reduces the

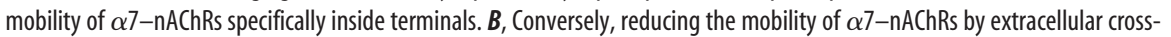
linking increases transmitter release, possibly via scaffold proteins such as ELKS1, reduces the mobility of GluA1s.

traversing synaptic space on the presynaptic side is similar to the values reported for $\alpha 7-\mathrm{nAChRs}$ in synaptic space on the postsynaptic side on both ciliary ganglion neurons and hippocampal interneuron dendrites (Fernandes et al., 2010; Gómez-Varela et al., 2012). This reduced mobility indicates the existence of molecular constraints on nicotinic receptors at the active zone.

For all three cases of $\alpha 7-n A C h R$ mobility examined, the shape of the MSD versus lag-time plot indicates restrained movement of the receptors when in synaptic space (Fig. 1C; Fernandes et al., 2010; Gómez-Varela et al., 2012). For postsynaptic $\alpha 7$-nAChRs, the constraint has been shown to depend primarily on interactions with scaffold proteins, e.g., PSD-95 or F-actin (Fernandes et al., 2010; Gómez-Varela et al., 2012). For presynaptic $\alpha 7-n A C h R s$, active zone-associated components may be key players. Proteomics here identified ELKS as a candidate for being associated with $\alpha 7-$ nAChRs. Because ELKS bind to Rab3a-interacting molecules (RIMs) and liprins (Wang et al., 2002; Ko et al., 2003), the ELKS1 link could embed $\alpha 7-n A C h R s$ in the scaffold, linking them to presynaptic sites. Additional analysis is required to determine whether ELKS1 is actually associated with $\alpha 7-\mathrm{nAChRs}$ and mediates the effects of $\alpha 7-\mathrm{nAChR}$ crosslinking on RRP size, as suggested by the RNAi experiments.

A major finding here is that crosslinking presynaptic $\alpha 7-$ $\mathrm{nAChRs}$ produces a substantial increase in transmitter release capability as measured by electrophysiology, FM4-64FX labeling, and Syn-Lum immunostaining. Several lines of evidence indicate that the increased capacity represents an increase in RRP size rather than a change in the steady-state rate of RRP refilling or other parameters. Crosslinking produced no change in the second phase of transmitter release triggered by sucrose, no change in the kinetics of release, and no change in the refilling rate of the
RRP. It did increase the initial release elicited by sucrose, which is an indication of RRP size, and it did increase mEPSC frequency with no change in mEPSC amplitude. That, together with the lack of change in number of synapses detectable by immunostaining, suggests that crosslinking $\alpha 7$-nAChRs may increase release capability at preexisting sites rather than creating more synapses de novo.

Long-term stimulation of $\alpha 7-\mathrm{nAChRs}$ can increase the number of glutamatergic synapses identified by immunostaining, mEPSC frequency, and ultrastructural analysis (Lozada et al., 2012). An increase in synapse number was not the basis for the increased release seen here because only relatively short time periods of $\alpha 7-$ $\mathrm{nAChR}$ crosslinking were required. In addition, changes in synapse number depended on $\alpha 7-$ nAChRs on the postsynaptic neuron (Lozada et al., 2012), whereas the effects seen here on release required presynaptic $\alpha 7-$ nAChRs.

How might immobilization of presynaptic $\alpha 7$-nAChRs affect transmitter release? The possibility of presynaptic $\alpha 7-$ nAChR association with active zone components suggests two mechanisms. ELKS1, for example, links to RIMs (Wang et al., 2002; Ko et al., 2003; Südhof, 2012) and could position $\alpha 7-\mathrm{nAChRs}$ near N$\mathrm{P} / \mathrm{Q}$ calcium channels and sites of transmitter release (Kaeser et al., 2012), optimizing the impact of an $\alpha 7-\mathrm{nAChR}$ calcium signal. It is well documented that presynaptic $\alpha 7-n A C h R s$ can promote transmitter release by virtue of their high relative permeability to calcium and activation of calcium release from internal stores (Bertrand et al., 1993; Séguéla et al., 1993; McGehee et al., 1995; Gray et al., 1996; Dickinson et al., 2008; Zhong et al., 2008; Albuquerque et al., 2009; Gu and Yakel, 2011). The size of the effective RRP can be influenced by calcium (Thanawala and Regehr, 2013). Furthermore, the efficacy of transmitter release is known to depend critically on the submicrometer location of calcium-permeable channels in the active zone (Augustine et al., 1991; Meinrenken et al., 2003; Schneggenburger and Neher, 2005).

A second possibility is that the interaction between $\alpha 7$ nAChRs and active zone components may increase RRP size by rearranging the presynaptic scaffold during the crosslinking rather than providing an acute effect on calcium-dependent transmitter release. The crosslinking of $\alpha 7-\mathrm{nAChRs} \mathrm{did,} \mathrm{in} \mathrm{fact,}$ rearrange proteins comprising the active zone (Fig. $7 B$ ). This could, for example, help constrain the brake on release thought to be imposed by ELKS (Kaeser et al., 2009). However, if ELKS is involved, yet to be explained is how synaptic silencing by TeT immobilizes $\alpha 7-$ nAChRs given that a global reduction in activity is thought to reduce ELKS at presynaptic terminals (Gundelfinger and Fejtova, 2012).

In either case, functional $\alpha 7-\mathrm{nAChRs}$ appear to be required for the enhancement of RRP by receptor crosslinking. This was inferred from the observation that MLA prevented the crosslinking from increasing RRP when added along with the $\mathrm{Ab}$, whereas MLA in the absence of crosslinking had no effect on RRP. Al- 
though the Biot-Bgt used in the crosslinking of $\alpha 7-\mathrm{nAChRs}$ is a competitive antagonist of the receptors, only a single Biot-Bgt need be bound for $\mathrm{Ab}$ tethering of a receptor to form a cluster. Unoccupied sites remaining on the homopentameric $\alpha 7-\mathrm{nAChR}$ would have permitted functionality (Williams et al., 2011). Activation of the receptors in culture could have resulted either from choline in the medium (Alkondon et al., 1997, 1999) or by ACh released from cholinergic neurons in the cultures (Frotscher et al., 1986, 2000). Indeed, application of choline was able to activate the crosslinked receptors (Fig. $3 D$ ).

Crosslinking $\alpha 7-n A C h R s$ likely did more than simply immobilize the receptors. It should have increased receptor number in clusters such as those at presynaptic sites. This is expected because individual Biot-Bgt-bound receptors would remain mobile until within range of a receptor cluster for linkage. Reduced diffusion and increased dwell time of $\alpha 7-n A C h R s$ in presynaptic space is certainly consistent with elevated receptor density at such sites, comprising a cluster that could serve as a seed for crosslinking. Consistent with this, crosslinking increased the mean size of $\alpha 7-$ nAChR clusters (Fig. $2 A$ ). When methods become available to image presynaptic $\alpha 7-\mathrm{nAChRs}$ directly, it will be interesting to determine how the number of clustered $\alpha 7-\mathrm{nAChRs}$ at presynaptic terminals varies with different physiological conditions.

The SPT approach allowed us to label and study specifically the dynamics of $\alpha 7-\mathrm{nAChRs}$ on axons. The differences seen in axonal versus dendritic $\alpha 7-\mathrm{nAChR}$ mobilities (Gómez-Varela et al., 2012) confirm that different populations can be distinguished in this way. An important challenge for the future will be identifying the molecular mechanisms responsible for reversibly recruiting $\alpha 7-\mathrm{nAChRs}$ to release sites as a function of regulatory need. Although the RNAi experiments initially implicate ELKS1, it is not clear how it participates or whether other components act as the primary sensors linking $\alpha 7-\mathrm{nAChR}$ mobility to the need for transmitter release. Additional analysis of complexes containing ELKS and $\alpha 7-$ nAChRs will be needed to identify the key players.

The relationship between $\alpha 7-\mathrm{nAChR}$ immobility and transmitter release suggests a homeostatic mechanism that sustains an appropriate capacity for transmitter release. The range over which the mechanism operates appears to be physiological. The observed increase in transmitter release resulting from crosslinking $\alpha 7-n A C h R s$ correlates with a decrease in the mobility of postsynaptic AMPA receptors, consistent with a downstream effect. Although the manipulation could not distinguish presynaptic versus postsynaptic $\alpha 7-\mathrm{nAChR}$ contributions to the effect, the change in AMPA receptor mobility is consistent with previous results for the inverse situation, namely the finding that decreasing glutamate release increases AMPA receptor mobility at postsynaptic sites (Ehlers et al., 2007). Although glutamate release was the primary focus here, presynaptic $\alpha 7-\mathrm{nAChRs}$ are found on many kinds of terminals throughout the CNS (McGehee et al., 1995; Gray et al., 1996; Alkondon and Albuquerque, 2001; Fabian-Fine et al., 2001; Dajas-Bailador and Wonnacott, 2004; Dickinson et al., 2008; Zhong et al., 2008; Gu and Yakel, 2011). That, and the pervasiveness of cholinergic innervation (Umbriaco et al., 1995; Descarries et al., 1997; Bansal et al., 2000; Hanson and Landmesser, 2003; Witten et al., 2010), suggest that the regulation seen here may be widespread in the nervous system.

\section{References}

Adesnik H, Nicoll RA, England PM (2005) Photoinactivation of native AMPA receptors reveals their real-time trafficking. Neuron 48:977-985. CrossRef Medline

Albuquerque EX, Pereira EF, Alkondon M, Rogers SW (2009) Mammalian nicotinic acetylcholine receptors: from structure to function. Physiol Rev 89:73-120. CrossRef Medline

Alkondon M, Albuquerque EX (2001) Nicotinic acetylcholine receptor alpha7 and alpha4beta2 subtypes differentially control GABAergic input to CA1 neurons in rat hippocampus. J Neurophysiol 86:3043-3055. Medline

Alkondon M, Pereira EF, Cortes WS, Maelicke A, Albuquerque EX (1997) Choline is a selective agonist of alpha7 nicotinic acetylcholine receptors in the rat brain neurons. Eur J Neurosci 9:2734-2742. CrossRef Medline

Alkondon M, Pereira EF, Eisenberg HM, Albuquerque EX (1999) Choline and selective antagonists identify two subtypes of nicotinic acetylcholine receptors that modulate GABA release from CA1 interneurons in rat hippocampal slices. J Neurosci 19:2693-2705. Medline

Ashby MC, Maier SR, Nishimune A, Henley JM (2006) Lateral diffusion drives øconstitutive exchange of AMPA receptors at dendritic spines and is regulated by spine morphology. J Neurosci 26:7046-7055. CrossRef Medline

Augustine GJ, Adler EM, Charlton MP (1991) The calcium signal for transmitter secretion from presynaptic nerve terminals. Ann NY Acad Sci 635: 365-381. CrossRef Medline

Bansal A, Singer JH, Hwang BJ, Xu W, Beaudet A, Feller MB (2000) Mice lacking specific nicotinic acetylcholine receptor subunits exhibit dramatically altered spontaneous activity patterns and reveal a limited role for retinal waves in forming $\mathrm{ON}$ and OFF circuits in the inner retina. J Neurosci 20:7672-7681. Medline

Bertrand D, Galzi JL, Devillers-Thiéry A, Bertrand S, Changeux JP (1993) Mutations at two distinct sites within the channel domain M2 alter calcium permeability of neuronal alpha 7 nicotinic receptor. Proc Natl Acad Sci U S A 90:6971-6975. CrossRef Medline

Biederer T, Scheiffele P (2007) Mixed-culture assays for analyzing neuronal synapse formation. Nat Protoc 2:670-676. CrossRef Medline

Campbell NR, Fernandes CC, Halff AW, Berg DK (2010) Endogenous signaling through $\alpha 7$-containing nicotinic receptors promotes maturation and integration of adult-born neurons in the hippocampus. J Neurosci 30:8734-8744. CrossRef Medline

Chang KT, Berg DK (2001) Voltage-gated channels block nicotinic regulation of CREB phosphorylation and gene expression in neurons. Neuron 32:855-865. CrossRef Medline

Czöndör K, Mondin M, Garcia M, Heine M, Frischknecht R, Choquet D, Sibarita JB, Thoumine OR (2012) Unified quantitative model of AMPA receptor trafficking at synapses. Proc Natl Acad Sci U S A 109:3522-3527. CrossRef Medline

Dajas-Bailador F, Wonnacott S (2004) Nicotinic acetylcholine receptors and the regulation of neuronal signalling. Trends Pharmacol Sci 25:317324. CrossRef Medline

Deng L, Kaeser PS, Xu W, Südhof TC (2011) RIM proteins activate vesicle priming by reversing autoinhibitory homodimerization of Munc13. Neuron 69:317-331. CrossRef Medline

Descarries L, Gisiger V, Steriade M (1997) Diffuse transmission by acetylcholine in the CNS. Prog Neurobiol 53:603-625. CrossRef Medline

Dickinson JA, Kew JN, Wonnacott S (2008) Presynaptic alpha 7- and beta 2-containing nicotinic acetylcholine receptors modulate excitatory amino acid release from rat prefrontal cortex nerve terminals via distinct cellular mechanisms. Mol Pharmacol 74:348-359. CrossRef Medline

Dudel J, Kuffler SW (1961) The quantal nature of transmission and spontaneous miniature potentials at the crayfish neuromuscular junction. J Physiol 155:514-529. Medline

Duguid IC, Smart TG (2009) Presynaptic NMDA receptors. In: Biology of the NMDA receptor (Van Dongen AM, ed), Ch 14. Boca Raton, FL: CRC.

Eccles JC (1964) Presynaptic inhibition in the spinal cord. Prog Brain Res 12:65-91. CrossRef Medline

Ehlers MD, Heine M, Groc L, Lee MC, Choquet D (2007) Diffusional trapping of GluR1 AMPA receptors by input-specific synaptic activity. Neuron 54:447-460. CrossRef Medline

Fabian-Fine R, Skehel P, Errington ML, Davies HA, Sher E, Stewart MG, Fine A (2001) Ultrastructural distribution of the $\alpha 7$ nicotinic acetylcholine receptor subunit in rat hippocampus. J Neurosci 21:7993-8003. Medline

Fernandes CC, Berg DK, Gómez-Varela D (2010) Lateral mobility of nicotinic acetylcholine receptors on neurons is determined by receptor composition, local domain, and cell type. J Neurosci 30:8841-8851. CrossRef Medline

Frotscher M, Schlander M, Léránth C (1986) Cholinergic neurons in the 
hippocampus a combined light- and electron-microscopic immunocytochemical study in the rat. Cell Tissue Res 246:293-301. CrossRef Medline

Frotscher M, Vida I, Bender R (2000) Evidence for the existence of nonGABAergic, cholinergic interneurons in the rodent hippocampus. Neuroscience 96:27-31. CrossRef Medline

Goetze B, Grunewald B, Baldassa S, Kiebler M (2004) Chemically controlled formation of a DNA/calcium phosphate coprecipitate: application for transfection of mature hippocampal neurons. J Neurobiol 60:517-525. CrossRef Medline

Gómez-Varela D, Schmidt M, Schoellerman J, Peters EC, Berg DK (2012) PMCA2 via PSD-95 controls calcium signaling by $\alpha 7$-containing nicotinic acetylcholine receptors on aspiny interneurons. J Neurosci 32:68946905. CrossRef Medline

Gray R, Rajan AS, Radcliffe KA, Yakehiro M, Dani JA (1996) Hippocampal synaptic transmission enhanced by low concentrations of nicotine. Nature 383:713-716. CrossRef Medline

Groc L, Heine M, Cognet L, Brickley K, Stephenson FA, Lounis B, Choquet D (2004) Differential activity-dependent regulation of the lateral mobilities of AMPA and NMDA receptors. Nat Neurosci 7:695-696. CrossRef Medline

Gu Z, Yakel JL (2011) Timing-dependent septal cholinergic induction of dynamic hippocampal synaptic plasticity. Neuron 71:155-165. CrossRef Medline

Gundelfinger ED, Fejtova A (2012) Molecular organization and plasticity of the cytomatrix at the active zone. Curr Opin Neurobiol 22:423-430. CrossRef Medline

Hanson MG, Landmesser LT (2003) Characterization of the circuits that generate spontaneous episodes of activity in the early embryonic mouse spinal cord. J Neurosci 23:587-600. Medline

Harms KJ, Tovar KR, Craig AM (2005) Synapse-specific regulation of AMPA receptor subunit composition by activity. J Neurosci 25:63796388. CrossRef Medline

Heine M, Groc L, Frischknecht R, Béique JC, Lounis B, Rumbaugh G, Huganir RL, Cognet L, Choquet D (2008) Surface mobility of postsynaptic AMPARs tunes synaptic transmission. Science 320:201-205. CrossRef Medline

Hoze N, Nair D, Hosy E, Sieben C, Manley S, Herrmann A, Sibarita JB, Choquet D, Holcman D (2012) Heterogeneity of AMPA receptor trafficking and molecular interactions revealed by superresolution analysis of live cell imaging. Proc Natl Acad Sci U S A 109:17052-17057. CrossRef Medline

Hu M, Liu QS, Chang KT, Berg DK (2002) Nicotinic regulation of CREB activation in hippocampal neurons by glutamatergic and nonglutamatergic pathways. Mol Cell Neurosci 21:616-625. CrossRef Medline

Jones S, Sudweeks S, Yakel JL (1999) Nicotinic receptors in the brain: correlating physiology with function. Trends Neurosci 22:555-561. CrossRef Medline

Kaeser PS, Deng L, Chávez AE, Liu X, Castillo PE, Südhof TC (2009) ELKS2alpha/CAST deletion selectively increases neurotransmitter release at inhibitory synapses. Neuron 64:227-239. CrossRef Medline

Kaeser PS, Deng L, Fan M, Südhof TC (2012) RIM genes differentially contribute to organizing presynaptic release sites. Proc Natl Acad Sci U S A 109:11830-11835. CrossRef Medline

Kawai H, Zago W, Berg DK (2002) Nicotinic $\alpha 7$ receptor clusters on hippocampal GABAergic neurons: regulation by synaptic activity and neurotrophins. J Neurosci 22:7903-7912. Medline

Khakh BS, Henderson G (2000) Modulation of fast synaptic transmission by presynaptic ligand-gated cation channels. J Auton Nerv Syst 81:110121. CrossRef Medline

Ko J, Na M, Kim S, Lee JR, Kim E (2003) Interaction of the ERC family of RIM-binding proteins with the liprin-alpha family of multidomain proteins. J Biol Chem 278:42377-42385. CrossRef Medline

Langer SZ (2008) Presynaptic autoreceptors regulating transmitter release. Neurochem Int 52:26-30. CrossRef Medline

Larsen RS, Corlew RJ, Henson MA, Roberts AC, Mishina M, Watanabe M, Lipton SA, Nakanishi N, Pérez-Otaño I, Weinberg RJ, Philpot BD (2011) NR3A-containing NMDARs promote neurotransmitter release and spike timing-dependent plasticity. Nat Neurosci 14:338-344. CrossRef Medline

Liu Z, Neff RA, Berg DK (2006) Sequential interplay of nicotinic and GABAergic signaling guides neuronal development. Science 314:16101613. CrossRef Medline

Lozada AF, Wang X, Gounko NV, Massey KA, Duan J, Liu Z, Berg DK (2012)
Glutamatergic synapse formation is promoted by $\alpha 7$-containing nicotinic acetylcholine receptors. J Neurosci 32:7651-7661. CrossRef Medline

Makino H, Malinow R (2009) AMPA receptor incorporation into synapses during LTP: the role of lateral movement and exocytosis. Neuron 64:381390. CrossRef Medline

McGehee DS, Heath MJ, Gelber S, Devay P, Role LW (1995) Nicotine enhancement of fast excitatory synaptic transmission in CNS by presynaptic receptors. Science 269:1692-1696. CrossRef Medline

Meinrenken CJ, Borst JG, Sakmann B (2003) Local routes revisited: the space and time dependence of the $\mathrm{Ca}^{2+}$ signal for phasic transmitter release at the rat calyx of Held. J Physiol 547:665-689. CrossRef Medline

Mercer AJ, Chen M, Thoreson WB (2011) Lateral mobility of presynaptic L-type calcium channels at photoreceptor ribbon synapses. J Neurosci 31:4397-4406. CrossRef Medline

Mikasova L, Groc L, Choquet D, Manzoni OJ (2008) Altered surface trafficking of presynaptic cannabinoid type 1 receptor in and out synaptic terminals parallels receptor desensitization. Proc Natl Acad Sci U S A 105:18596-18601. CrossRef Medline

Miwa JM, Freedman R, Lester HA (2011) Neural systems governed by nicotinic acetylcholine receptors: emerging hypotheses. Neuron 70:20-33. CrossRef Medline

Opazo P, Labrecque S, Tigaret CM, Frouin A, Wiseman PW, De Koninck P, Choquet D (2010) CaMKII triggers the diffusional trapping of surface AMPARs through phosphorylation of stargazin. Neuron 67:239-252. CrossRef Medline

Pyle JL, Kavalali ET, Piedras-Rentería ES, Tsien RW (2000) Rapid reuse of readily releasable pool vesicles at hippocampal synapses. Neuron 28:221231. CrossRef Medline

Rosenmund C, Stevens CF (1996) Definition of the readily releasable pool of vesicles at hippocampal synapses. Neuron 16:1197-1207. CrossRef Medline

Schneggenburger R, NeherE (2005) Presynaptic calcium and control of vesicle fusion. Curr Opin Neurobiol 15:266-274. CrossRef Medline

Séguéla P, Wadiche J, Dineley-Miller K, Dani JA, Patrick JW (1993) Molecular cloning, functional properties, and distribution of rat brain $\alpha 7$ : a nicotinic cation channel highly permeable to calcium. J Neurosci 13:596604. Medline

Südhof TC (2000) The synaptic vesicle cycle revisited. Neuron 28:317-320. CrossRef Medline

Südhof TC (2012) The presynaptic active zone. Neuron 75:11-25. CrossRef Medline

Tardin C, Cognet L, Bats C, Lounis B, Choquet D (2003) Direct imaging of lateral movements of AMPA receptors inside synapses. EMBO J 22:4656 4665. CrossRef Medline

Thanawala MS, Regehr WG (2013) Presynaptic calcium influx controls neurotransmitter release in part by regulating the effective size of the readily releasable pool. J Neurosci 33:4625-4633. CrossRef Medline

Triller A, Choquet D (2008) New concepts in synaptic biology derived from single-molecule imaging. Neuron 59:359-374. CrossRef Medline

Umbriaco D, Garcia S, Beaulieu C, Descarries L (1995) Relational features of acetylcholine, noradrenaline, serotonin and GABA axon terminals in the stratum radiatum of adult rat hippocampus (CA1). Hippocampus 5:605-620. CrossRef Medline

Wang Y, Liu X, Biederer T, Südhof TC (2002) A family of RIM-binding proteins regulated by alternative splicing: Implications for the genesis of synaptic active zones. Proc Natl Acad Sci U S A 99:14464-14469. CrossRef Medline

Williams DK, Stokes C, Horenstein NA, Papke RL (2011) The effective opening of nicotinic acetylcholine receptors with single agonist binding sites. J Gen Physiol 137:369-384. CrossRef Medline

Witten IB, Lin SC, Brodsky M, Prakash R, Diester I, Anikeeva P, Gradinaru V, Ramakrishnan C, Deisseroth K (2010) Cholinergic interneurons control local circuit activity and cocaine conditioning. Science 330:16771681. CrossRef Medline

Xu J, Zhu Y, Heinemann SF (2006) Identification of sequence motifs that target neuronal nicotinic receptors to dendrites and axons. J Neurosci 26:9780-9793. CrossRef Medline

Zhong C, Du C, Hancock M, Mertz M, Talmage DA, Role LW (2008) Presynaptic type III neuregulin 1 is required for sustained enhancement of hippocampal transmission by nicotine and for axonal targeting of $\alpha 7$ nicotinic acetylcholine receptors. J Neurosci 28:9111-9116. CrossRef Medline 